\title{
PENGARUH STRUKTUR MODAL DAN KEPEMILIKAN INSTITUSIONAL TERHADAP NILAI PERUSAHAAN PADA PERUSAHAAN KONSTRUKSI YANG TERDAFTAR DI BURSA EFEK INDONESIA
}

\author{
Endang Sepriani Simangunsong ${ }^{1}$, Herman Karamoy ${ }^{2}$, Rudy J. Pusung ${ }^{3}$ \\ ${ }^{1,2,3}$ Jurusan Akuntansi, Fakultas Ekonomi dan Bisnis, Universitas Sam Ratulangi, Jl. Kampus Bahu, Manado, \\ 95115, Indonesia \\ E-mail : endangsimangunsong41@yahoo.com
}

\begin{abstract}
The Company was established not only to profit from the operations of the company. Getting profit is a short-term goal of a company. The main purpose and the long-term goal of a company is to maximize the company's wealth or value (value of the firm). The purpose of this study is to determine the effect of capital structure and institutional ownership of firm value on construction companies listed on the BEI period 2014-2016. Sampling method is by purposive sampling method. The sample of this research are 19 construction companies listed on BEI. The analysis tool used is multiple linear regression. The results showed that the capital structure has a positive effect on firm value, which means that there is partially positive influence between capital structure variable to firm value. Partial institutional ownership does not have a positive effect on the value of companies in construction companies listed on the BEI period 2014-2016.
\end{abstract}

Keywords: Capital Structure, Institutional ownership, value of the firm.

\section{PENDAHULUAN}

Perusahaan didirikan tidak hanya untuk memperoleh laba dari kegiatan operasi yang dilakukan oleh perusahaan. Tujuan perusahaan membuat produk adalah untuk mendapatkan laba, yakni imbalan yang diperoleh perusahaan dari penyediaan suatu produk bagi konsumen. Produk yang dimaksud adalah barang dan jasa. Laba yang diperoleh perusahaan merupakan salah satu dari sekian banyak tujuan yang hendak dicapai perusahaan. Perusahaan secara garis besar memiliki tujuan jangka panjang dan tujuan jangka pendek. Tujuan utama perusahaan adalah untuk memaksimumkan kekayaan atau nilai perusahaan (value of the firm). Sasaran jangka panjang dari suatu perusahaan bukan untuk memaksimumkan keuntungan yang diperoleh, melainkan bagaimana memperbesar nilai perusahaan secara berkesinambungan (Tasman dan Aima, 2013:20). Fama menyatakan bahwa nilai perusahaan akan tercermin dari harga pasar sahamnya (Hermuningsih, 2013).

Struktur modal perusahaan menggambarkan perbandingan antara total hutang dan total modal yang dimiliki oleh perusahaan (Haryono, 2017). Penggunaan hutang yang tinggi menunjukkan bahwa kegiatan perusahaan lebih besar dibiayai oleh modal yang bersumber dari luar (hutang) dibandingkan dengan modal yang berasal dari dalam perusahaan. Apabila sumber pendanaan perusahaan didominasi oleh hutang maka resiko perusahaan juga akan meningkat seiring dengan peningkatan jumlah hutang perusahaan tersebut. Resiko yang meningkat akan berdampak pada nilai perusahaan dikarenakan persepsi investor terhadap perusahaan juga akan berpengaruh. Investor akan cenderung memilih perusahaan dengan hutang yang rendah dikarenakan resiko yang juga kecil. Hutang tidak juga selalu berdampak buruk terhadap masa depan perusahaan hal ini dikarenakan oleh penggunaan hutang yang masih dalam titik optimal. Posisi struktur modal yang berada dibawah titik optimal, maka setiap penambahan hutang akan meningkatkan nilai perusahaan, tetapi setelah melewati titik optimal tersebut peningkatan penggunaan hutang dapat menurunkan nilai perusahaan. 
Struktur kepemilikan adalah komposisi kepemilikan saham oleh pihak internal ataupun pihak eksternal perusahaan. Struktur kepemilikan pada penelitian ini lebih berfokus pada kepemilikan institusional sebagai konsentrasi kepemilikan saham perusahaan oleh pihak luar (outsider ownership). Perusahaan dengan kepemilikan institusional yang besar mengindikasikan kemampuannya untuk memonitor pihak manajer perusahaan yang artinya secara tidak langsung investor institusional bertindak sebagai pengawas yang mengawasi kinerja dari manajer perusahaan tersebut. Semakin tinggi kepemilikan institusional maka penggunaan aset perusahaan akan semakin efisien sehingga investor institusional diharapkan juga dapat bertindak sebagai pencegahan terhadap pemborosan yang dilakukan oleh manajemen. Semakin besar kepemilikan oleh pihak institusi, maka akan semakin besar dorongan pihak institusi untuk mengawasi manajemen dan akibatnya akan memberikan dorongan yang lebih besar untuk mengoptimalkan kinerja perusahaan sehingga dengan kinerja yang baik maka nilai perusahaan juga akan meningkat.

Tujuan penelitian yang ingin dicapai dalam penelitian ini sebagai berikut.

1 Untuk mengetahui pengaruh struktur modal terhadap nilai perusahaan pada perusahaan konstruksi yang terdaftar di Bursa Efek Indonesia.

2 Untuk mengetahui pengaruh kepemilikan institusional terhadap nilai perusahaan pada perusahaan konstruksi yang terdaftar di Bursa Efek Indonesia.

\section{TINJAUAN PUSTAKA}

\subsection{Struktur Modal}

Gitman mengatakan bahwa struktur modal perusahaan menggambarkan perbandingan antara total hutang dan total modal yang dimiliki oleh perusahaan (Haryono, 2017). Struktur modal juga berhubungan dengan sumber pendanaan perusahaan. Struktur modal memiliki beberapa teori, di antaranya adalah:

\section{$1 \quad$ Trade-Off Theory}

Trade-off theory merupakan teori struktur modal yang didasarkan pada cost dan benefit antara biaya modal dan keuntungan penggunaan hutang yaitu antara biaya kebangkrutan dan keuntungan pajak (Pangulu, 2014). Berdasarkan pada model trade-off, setiap perusahaan harus menentukan target struktur modal dimana biaya dan keuntungan dari penggunaan hutang adalah sama. Hal ini dikarenakan struktur modal tersebut akan memaksimalkan nilai perusahaan. Menurut pendapat Myers, dalam implikasi trade off theory, entitas-entitas bisnis akan mencari tingkat utang yang akan memberikan mereka manfaat pajak untuk setiap ketambahan utang selain biaya-biaya yang mungkin muncul akibat adanya kesenjangan keuangan (Pontoh dan Budiarso, 2018.

\section{$2 \quad$ Pecking Order Theory}

Berdasarkan pecking order theory, perusahaan akan lebih menyukai pendanaan internal daripada pendanaan eksternal. Myers dan Majluf menunjukkan bahwa pecking order theory adalah salah satu teori yang mendasarkan pada asimetri informasi akan mempengaruhi struktur modal perusahaan dengan cara membatasi akses pada sumber pendanaan dari luar (Haryono, 2017). Struktur modal dalam penelitian ini di-proxy-kan menggunakan debt to equity ratio (DER), yaitu rasio yang membandingkan antara total hutang dengan total modal, dimana semakin besar nilai DER ini, maka jumlah hutang yang mampu dijamin dengan modal sendiri perusahaan semakin kecil. Rumus menghitung DER yaitu:

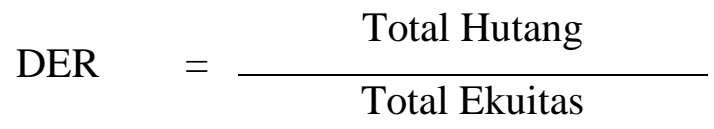




\subsection{Kepemilikan Institusional}

Struktur Kepemilikan yang berfokus pada kepemilikan institusional merupakan proporsi saham perusahaan yang dimiliki oleh institusi atau lembaga, seperti bank, perusahaan asuransi, perusahaan investasi atau institusi lainnya. Kepemilikan institusional berperan sebagai monitoring agent yang melakukan pengawasan optimal terhadap perilaku manajemen di dalam menjalankan perannya mengelola perusahaan (Sugiarto dalam Sari, 2016). Tingkat kepemilikan institusional yang tinggi akan menimbulkan usaha pengawasan yang lebih besar oleh pihak investor institusional sehingga dapat mengahalangi perilaku serakah atau opportunistic manajer. Semakin besar kepemilikan saham oleh investor institusional, maka semakin besar kekuatan suara dan dorongan institusi keuangan untuk mengawasi manajemen, sehingga akan memberikan dorongan yang lebih besar untuk meningkatkan kinerja perusahaan yang dapat mengoptimalkan nilai perusahaan. Adapun rumus untuk menghitung kepemilikan saham oleh institusi yaitu:

$$
\text { KPI }=\frac{\text { Jumlah Saham yang Dimiliki Oleh Institusi }}{\text { Jumlah Saham Beredar }} \quad 100
$$

\subsection{Nilai Perusahaan}

Nilai perusahaan didefinisikan sebagai persepsi investor terhadap tingkat keberhasilan perusahaan dalam mengelola sumber daya. Fama menyatakan bahwa nilai perusahaan akan tercermin dari harga pasar sahamnya (Hermuningsih, 2013). Semakin tinggi harga sahamnya maka semakin tinggi pula nilai perusahaan. Tingginya nilai perusahaan merupakan keinginan para pemegang saham karena dengan nilai perusahaan yang tinggi menunjukkan kemakmuran pemegang saham juga tinggi. Oleh karena itu, nilai perusahaan adalah persepsi investor terhadap perusahaan yang selalu dikaitkan dengan harga saham. Harga saham yang digunakan dalam penelitian ini adalah harga saham pada akhir tahun atau closing price. Nilai perusahaan dapat dirumuskan sebagai berikut:

$$
\text { PBV }=\frac{\text { Harga Pasar Per Lembar Saham }}{\text { Nilai Buku Per Lembar Saham }}
$$

\subsection{Hipotesis Penelitian}

Pada bagian ini akan dijelaskan mengenai pengembangan hipotesis-hipotesis penelitian dengan dasar penelitian-penelitian terdahulu.Terdapat dua hipotesis penelitian yang akan dijabarkan sebagai berikut:

H1: Struktur modal berpengaruh positif terhadap nilai perusahaan

H2: Kepemilikan institusional berpengaruh positif terhadap nilai perusahaan.

\section{METODE PENELITIAN}

\subsection{Jenis Penelitian}

Penelitian ini menggunakan metode deskriptif dengan pendekatan kuantitatif. Penelitian deskriptif adalah penelitian yang dilakukan untuk mengetahui nilai masing-masing variabel, baik satu variabel atau lebih sifatnya independen tanpa membuat hubungan maupun perbandingan dengan variabel yang lain (Sujarweni, 2015:49). Pendekatan kuantitatif adalah pendekatan yang dilakukan dengan cara pencatatan dan penganalisaan data hasil penelitian secara eksak dengan menggunakan perhitungan statistik.

\subsection{Tempat dan Waktu Penelitian}

Penelitian ini mengambil data penelitian di Pojok Bursa Efek Indonesia, yang beralamat di Laboratorium Pasar Modal dan Galeri Investasi Bursa Efek Indonesia 
Universitas Sam Ratulangi Manado. Waktu penelitian ini dimulai dari bulan Januari 2018 sampai dengan bulan April 2018.

\subsection{Populasi dan Teknik Pengambilan Sampel}

Populasi dalam penelitian ini adalah seluruh perusahaan konstruksi yang terdaftar di BEI selama periode 2014-2016. Teknik pengambilan sampel dilakukan dengan purposive sampling yaitu penentuan sampel dengan target atau kriteria yang telah ditetapkan oleh peneliti. Adapun objek dalam penelitian ini adalah perusahaan konstruksi yang terdaftar di Bursa Efek Indonesia (BEI) selama tahun 2014-2016 yang berjumlah 34 perusahaan konstruksi yang sudah go public dan dari 34 perusahaan tersebut diperoleh 19 sampel penelitian yang memenuhi kriteria yang telah ditetapkan.

Adapun kriteria yang akan digunakan untuk memilih sampel dalam penelitian ini adalah sebagai berikut:

1 Perusahaan konstruksi yang terdaftar di Bursa Efek Indonesia sebelum 2014 dan masih terdaftar hingga tahun 2016.

2 Perusahaan konstruksi yang mempublikasikan secara lengkap dan berturut-turut laporan tahunan (annual report) dan laporan keuangan tahunan perusahaan dari tahun 2014 sampai tahun 2016.

3 Perusahaan yang memiliki proporsi kepemilikan institusional selama periode 20142016.

\subsection{Metode Analisis}

Analisis data berisi pengujian data perusahaan konstruksi yang terdaftar di Bursa Efek Indonesia (BEI). Analisis data yang digunakan dalam penelitian ini yaitu Uji Regresi Linear Berganda. Uji Regresi Linear Berganda yaitu adalah hubungan secara linear antara dua atau lebih variabel independen $(\mathrm{X})$ dengan variabel dependen (Y). Pengujian regresi linear berganda di awali dengan Uji Asumsi Klasik. Dengan adanya pengujian ini diharapkan agar model regresi yang diperoleh dapat dipertanggungjawabkan. Oleh karena itu, perlu dilakukan uji asumsi klasik yang terdiri dari Uji Normalitas, Uji Multikolinearitas, Uji Heteroskedastisitas, dan sebelum melakukan Uji Regresi dan Uji Hipotesis.

\section{HASIL ANALISIS DAN PEMBAHASAN \\ 4.1 Hasil Analisis \\ 4.1.1 Uji Outlier}

Deteksi adanya outlier univariate dapat dilakukan dengan menentukan nilai ambang batas yang dikategorikan sebagai outlier dengan cara mengkonversikan nilai data penelitian kedalam standart score atau disebut juga dengan $Z$-score yang mempunyai nilai rata-rata nol dan standart deviasi satu. Observasi data yang memiliki Z-score $\geq \pm 1,96$ akan dikategorikan sebagai outlier. Hasil uji outlier pada stuktur modal $\left(\mathrm{X}_{1}\right)$, kepemilikan intstitusional $\left(\mathrm{X}_{2}\right)$ dan nilai perusahaan $(\mathrm{Y})$ adalah:

Descriptive Statistics

\begin{tabular}{|l|l|l|l|l|l|}
\hline & $\mathbf{N}$ & \multicolumn{1}{|c|}{ Minimum } & \multicolumn{1}{|c|}{ Maximum } & \multicolumn{1}{c|}{ Mean } & $\begin{array}{c}\text { Std. } \\
\text { Deviation }\end{array}$ \\
\hline $\begin{array}{l}\text { Zscore: Struktur } \\
\text { Modal }\end{array}$ & 57 & -3.27318 & 3.79031 & $-1.8814148 \mathrm{E}-16$ & 1.00000000 \\
\hline $\begin{array}{l}\text { Zscore: } \\
\text { Kepemilikan } \\
\text { Institusional }\end{array}$ & 57 & -1.80078 & 1.60161 & .0000000 & 1.00000000 \\
\hline $\begin{array}{l}\text { Zscore: Nilai } \\
\text { Perusahaan }\end{array}$ & 57 & -1.57689 & 4.51535 & $-6.3424133 \mathrm{E}-17$ & 1.00000000 \\
\hline Valid N (listwise) & 57 & & & & \\
\hline
\end{tabular}

Sumber : Hasil Pegolahan Data Menggunakan Aplikasi SPSS Tahun 2018 
Berdasarkan hasil descriptive statistics pada tabel diatas menunjukkan bahwa pada variabel penelitian yaitu struktur modal (DER), kepemilikan institusional (KPI) dan nilai perusahaan (PBV) terdapat outlier karena nilai z-score yang dihasilkan diluar selang $\pm 1,96$. Dengan demikian, jumlah data outlier yaitu sebanyak 4 (empat) data sehingga jumlah observasi untuk uji selanjutnya sebanyak $57-4=53$ (lima puluh tiga) data atau observasi.

\subsubsection{Uji Asumsi Klasik}

Uji asumsi klasik diterapkan guna memperoleh hasil estimasi yang valid secara ekonometri, dalam arti bahwa analisis yang akan diterapkan tidak menyimpang dari teori ekonomi. Adapun, uji asumsi klasik yang diterapkan dalam penelitian ini meliputi uji multikolinieritas, dan uji heteroskedastisitas.

a Uji Normalitas

Uji normalitas bertujuan untuk menguji apakah data kontinu berdistribusi normal atau tidak. Sehingga apabila data kontinu telah berdistribusi normal maka bisa dilanjutkan ke tahap berikutnya yakni uji-t, korelasi dan regresi dapat dilaksanakan. Untuk menguji apakah data bersifat normal atau tidak maka peneliti menggunakan analisa Kolmogrov-Smirnov. Hasil penelitian sebagai berikut:

\section{One-Sample Kolmogorov-Smirnov Test}

\begin{tabular}{|ll|l|}
\hline & & Unstandardized Residual \\
\hline $\mathrm{N}$ & & \multicolumn{1}{|c|}{53} \\
\hline Normal Parameters $^{\mathrm{a}}$ & Mean & .0000000 \\
\hline & Std. Deviation & .98933179 \\
\hline Most Extreme Differences & Absolute & .167 \\
\hline & Positive & .167 \\
\hline & Negative & -.122 \\
\hline Kolmogorov-Smirnov Z & & \multicolumn{2}{c|}{1.214} \\
\hline Asymp. Sig. (2-tailed) &. & .105 \\
\hline
\end{tabular}

Sumber : Hasil Pegolahan Data Menggunakan Aplikasi SPSS Tahun 2018

Dari tampilan output SPSS di atas menunjukkan bahwa angka signifikansi atau asymp. Sig. (2-tailed) yang diperoleh sebesar 0,105 dimana nilai ini melebihi 0,05 (dalam kasus ini menggunakan taraf signifikansi sebesar 5\% atau $\alpha=5 \%$ ) sehingga residual mengikuti distribusi normal.

b Uji Multikolinieritas

Uji multikolinieritas dilakukan dengan melihat tolerance value dan value inflating factor (VIF). Sujarweni, (2015: 159), memberi rule of thumb bahwa bila VIF > 1,0 atau nilai tolerance $<0,10$ maka terjadi multikolinearitas. Apabila hasil analisis menunjukkan nilai VIF dibawah nilai 10 maka berarti tidak terjadi multikolinearitas. Nilai VIF (Variance Inflation Factor) dari variabel penelitian dapat ditunjukkan pada tabel berikut:

\section{Coefficients}

\begin{tabular}{|c|c|c|}
\hline \multirow{2}{*}{ Model } & \multicolumn{2}{|c|}{$\begin{array}{c}\text { Collinearity } \\
\text { Statistics }\end{array}$} \\
\cline { 2 - 3 } & Tolerance & VIF \\
\hline (Constant) & & 1.001 \\
\hline Struktur Modal & .999 & 1.001 \\
\hline Kepemilikan Institusional & .999 & \\
\hline
\end{tabular}

Sumber : Hasil Pegolahan Data Menggunakan Aplikasi SPSS Tahun 2018

Hasil perhitungan nilai Variance Inflation Factor (VIF) yang menunjukkan hal yang sama yaitu tidak ada satu variabel yang memiliki nilai VIF lebih dari 10. Hal ini dibuktikan 
dengan besarnya nilai VIF pada variabel struktur modal (DER) yaitu sebesar 1.001 dan pada kepemilikan institusional (KPI) yaitu sebesar 1,001 lebih kecil dari 10 dan nilai tersebut hanya berkisar pada angka 1, sehingga kesimpulannya bahwa variabel struktur modal dan kepemilikan institusional terbebas dari asumsi klasik multikolinieritas karena hasilnya lebih kecil daripada 10.

c Uji Heteroskedastisitas

Heteroskedastisitas dapat diidentifikasikan dengan cara menghitung koefisien korelasi Rank Spearman antara nilai residual dengan seluruh variabel bebas. Hasil dari uji Rank Spearman adalah sebagai berikut :

Hasil Korelasi Rank Spearman

\begin{tabular}{|l|l|l|}
\hline Variabel & $\begin{array}{l}\text { Tingkat } \\
\text { signifikansi }\end{array}$ & Rank spearman \\
\hline Struktur Modal & 0.622 & -0.069 \\
\hline Kepemilikan Institusional & 0.477 & -0.100 \\
\hline
\end{tabular}

Sumber : Hasil Pegolahan Data Menggunakan Aplikasi SPSS Tahun 2018

Berdasarkan tabel di atas, dapat disimpulkan bahwa model regresi linier berganda yang dihasilkan tidak terjadi heteroskedastisitas, karena tingkat signifikansi pada variabel struktur modal (DER) dan kepemilikan institusional (KPI) melebihi 5\% (sig > 5\%).

\subsubsection{Analisis Regresi Linier Berganda}

Dalam penelitian ini, pengujian hipotesisnya menggunakan regresi linier berganda yang bertujuan untuk mencari pengaruh dua atau lebih variabel bebas $(\mathrm{X})$ terhadap variabel terikat (Y). Variabel bebas (X) dalam penelitian ini yaitu struktur modal yang di Proxy-kan dengan debt to equity ratio (DER) dan kepemilikan institusional (KPI) dan variabel terikat (Y) yaitu nilai perusahaan yang diukur dengan price to book value (PBV). Hasil uji regresi linier berganda dalam penelitian ini dapat dilihat dalam tabel berikut:

\begin{tabular}{|c|c|c|c|c|c|}
\hline \multicolumn{6}{|c|}{ Coefficients } \\
\hline \multirow[t]{2}{*}{ Model } & \multicolumn{2}{|l|}{ UnstandardizedCoefficients } & \multirow{2}{*}{$\begin{array}{c}\begin{array}{c}\text { Standardized } \\
\text { Coefficients }\end{array} \\
\text { Beta }\end{array}$} & \multirow[t]{2}{*}{$\mathrm{t}$} & \multirow[t]{2}{*}{ Sig. } \\
\hline & B & $\begin{array}{l}\text { Std. } \\
\text { Error }\end{array}$ & & & \\
\hline (Constant) & 1.754 & .383 & & 4.586 & .000 \\
\hline $\begin{array}{c}\text { Struktur } \\
\text { Modal }\end{array}$ & .216 & .060 & .439 & 3.586 & .001 \\
\hline $\begin{array}{l}\text { Kepemilikan } \\
\text { Institusional }\end{array}$ & -.013 & .007 & -.226 & -1.849 & .070 \\
\hline
\end{tabular}

Sumber : Hasil Pegolahan Data Menggunakan Aplikasi SPSS Tahun 2018

Berdasarkan hasil dari tabel di atas dapat dikembangkan dengan menggunakan model persamaan regresi linier berganda sebagai berikut:

$\mathrm{Y}=1,754+0,216 \mathrm{X} 1-0,013 \mathrm{X} 2$

1. Konstanta sebesar 1,754 artinya jika struktur modal dan kepemilikan institusional tidak ada maka nilai perusahaan sebesar 1,754 .

2. Koefisien regresi X1 yang merupakan variabel struktur modal sebesar 0,216 artinya setiap kenaikan satu satuan variabel struktur modal yang diukur dengan debt to equity ratio (DER) akan meningkatkan nilai perusahaan (PBV) sebesar 0,216. Dan sebaliknya, setiap penurunan satu satuan struktur modal (DER), akan menurunkan nilai perusahaan (PBV) sebesar 0,216 dengan anggapan bahwa kepemilikan institusional tetap. Tanda 
(+) menunjukkan arah hubungan yang searah antara variabel struktur modal (DER) dengan nilai perusahaan (PBV).

3. Koefisien regresi X2 yang merupakan variabel kepemilikan institusional sebesar -0,013 artinya setiap kenaikan satu satuan kepemilikan institusional akan menurunkan nilai perusahaan (PBV) sebesar 0,013. Dan sebaliknya, setiap penurunan satu satuan kepemilikan institusional, akan meningkatkan nilai perusahaan sebesar 0,013 dengan anggapan bahwa struktur modal tetap. Tanda (-) menunjukkan arah hubungan yang berlawanan antara variabel kepemilikan institusional dengan nilai perusahaan (PBV).

\subsubsection{Koefisien Determinasi $\left(\mathbf{R}^{2}\right)$}

Koefisien determinasi $\left(\mathrm{R}^{2}\right)$ mengukur seberapa jauh kemampuan model dalam menerangkan variasi variabel nilai perusahaan. Nilai koefisien determinasi antara 0 dan 1 . Nilai $\mathrm{R}^{2}$ yang mendekati satu berarti variabel independen penelitian memberikan hampir semua informasi yang dibutuhkan untuk memprediksi variasi variabel nilai perusahaan.

\section{Model Summary}

\begin{tabular}{|l|l|l|l|l|}
\hline Model & R & R Square & $\begin{array}{l}\text { Adjusted } \\
\text { Square }\end{array}$ & $\begin{array}{l}\text { Std. Error of } \\
\text { the Estimate }\end{array}$ \\
\hline 1 & $.501^{\mathrm{a}}$ & .251 & .221 & 1.00892 \\
\hline
\end{tabular}

Sumber : Hasil Pegolahan Data Menggunakan Aplikasi SPSS Tahun 2018

Dari tabel 4.9. di atas, dapat dilihat bahwa angka koefisien determinasi $\left(\mathrm{R}^{2}\right)$ sebesar 0,251. Hal ini berarti kemampuan variabel struktur modal dan kepemilikan institusional dalam menerangkan variasi perubahan variabel nilai perusahaan sebesar $25,1 \%$ sedangkan sisanya sebesar 74,9\% (100-25,1\%) diterangkan oleh faktor-faktor lain di luar model regresi yang dianalisis.

\subsubsection{Uji Hipotesis}

a Uji t (Uji Parsial)

Pengujian hipotesis secara parsial yaitu untuk mengetahui ada tidaknya pengaruh masing-masing variabel independen yaitu struktur modal dan kepemilikan institusional terhadap variabel dependen yaitu nilai perusahaan yang dilakukan dengan uji t. Adapun hasil dapat dilihat pada Tabel 4.10. sebagai berikut:

\section{Coefficients}

\begin{tabular}{|l|l|l|l|l|l|}
\hline \multirow{2}{*}{ Model } & \multicolumn{2}{|l|}{$\begin{array}{l}\text { Unstandardized } \\
\text { Coefficients }\end{array}$} & $\begin{array}{l}\text { Standardized } \\
\text { Coefficients }\end{array}$ & t & \multirow{2}{*}{ Sig. } \\
\cline { 2 - 6 } & B & Std. Error & Beta & & .000 \\
\hline $\begin{array}{l}\text { (Constant) } \\
\begin{array}{l}\text { Struktur } \\
\text { Modal }\end{array}\end{array}$ & .216 & .383 & & 4.586 & .001 \\
\hline $\begin{array}{l}\text { Kepemilikan } \\
\text { Institusional }\end{array}$ & -.013 & .060 & .439 & 3.586 & .070 \\
\hline
\end{tabular}

Sumber : Hasil Pegolahan Data Aplikasi SPSS Tahun 2018

Hasil uji t diatas dapat disimpulkan bahwa pada variabel struktur modal diperoleh $\mathrm{t}_{\text {hitung }}$ sebesar 3,586 dengan signifikansi sebesar 0,001 yang nilainya dibawah 0,05. Dengan demikian $\mathrm{H} 1$ diterima, yang artinya secara parsial terdapat pengaruh positif signifikan antara variabel struktur modal terhadap nilai perusahaan. Sedangkan variabel kepemilikan institusional diperoleh $t_{\text {hitung }}$ sebesar -1,849 dengan probabilitas sebesar 0,070 yang nilainya 
diatas 0,05 . Dengan demikian $\mathrm{H} 2$ ditolak, yang artinya secara parsial tidak terdapat pengaruh positif signifikan antara variabel kepemilikan institusional terhadap nilai perusahaan.

b Uji F (Uji Simultan)

Uji Simultan (uji F) ini melibatkan kedua variabel bebas (struktur modal dan struktur kepemilikan) terhadap variabel terikat (nilai perusahaan) dalam menguji ada atau tidaknya pengaruh yang signifikan secara simultan atau bersama-sama (Sunyoto, 2013:54).

ANOVA

\begin{tabular}{|l|l|l|l|l|l|}
\hline \multicolumn{1}{|c|}{ Model } & \multicolumn{1}{|c|}{$\begin{array}{c}\text { Sum of } \\
\text { Squares }\end{array}$} & \multicolumn{1}{c|}{ df } & \multicolumn{1}{c|}{$\begin{array}{c}\text { Mean } \\
\text { Square }\end{array}$} & \multicolumn{1}{c|}{ F } & Sig. \\
\hline Regression & 17.095 & 2 & 8.547 & 8.397 & $.001^{\mathrm{a}}$ \\
\hline Residual & 50.896 & 50 & 1.018 & & \\
\hline Total & 67.991 & 52 & & & \\
\hline
\end{tabular}

Sumber : Hasil Pegolahan Data Aplikasi SPSS Tahun 2018

Berdasarkan tabel 4.11 di atas, didapat F-hitung sebesar 8,397 dengan signifikansi sebesar 0,001 yang nilainya dibawah 0,05 . Hal ini menunjukkan bahwa secara simultan variabel struktur modal dan kepemilikan institusional berpengaruh signifikan (bersama-sama) terhadap nilai perusahaan.

\subsection{Pembahasan}

a Pengaruh Struktur Modal Terhadap Nilai Perusahaan

Hasil penelitian ini yang menyatakan bahwa struktur modal berpengaruh signifikan positif terhadap nilai perusahaan dimana struktur modal diukur dengan debt to equity ratio (DER) dan nilai perusahaan diukur dengan price to book value (PBV) menandakan hubungan antara struktur modal nilai perusahaan adalah sejalan yang artinya bahwa setiap terjadi kenaikan nilai dari debt to equity ratio (DER) akan menyebabkan kenaikan pada nilai perusahaan (PBV). Banyak peneliti yang telah melakukan penelitian terkait dengan pengaruh sruktur modal terhadap nilai perusahaan antara lain Meythi, et al (2012) menunjukkan bahwa struktur modal tidak berpengaruh terhadap nilai perusahaan. Sedangkan hasil penelitian ini pada variabel struktur modal yang diukur dengan debt to equity ratio (DER) adalah struktur modal berpengaruh signifikan positif terhadap nilai perusahaan pada perusahaan konstruksi yang terdaftar di Bursa Efek Indonesia, dilihat dari nilai thitung sebesar 3,586 dengan probabilitas kurang dari $5 \%(0,05)$ yaitu sebesar 0,001 .

Pengaruh signifikan dan positif ini sesuai teori trade-off menyatakan bahwa penggunaan hutang akan meningkakan nilai perusahaan sampai pada titik tertentu. struktur modal optimal diperoleh dengan menyeimbangkan keuntungan tax shield akibat hutang dengan financial distress cost dan agency cost sehingga keuntungan dan biaya dari hutang saling trade-off satu sama lain, sehingga antara biaya dan keuntungan dari penggunaan hutang adalah sama. Perusahaan dengan menyatakan bahwa adanya peningkatan jumlah hutang dalam struktur modal pada suatu perusahaan menandakan bahwa perusahaan yakin akan prospek pendapatan perusahaan di masa yang akan datang sehingga perusahaan tidak perlu takut akan kegagalan pembayaran utang beserta dengan bunganya. Berdasarkan pecking order theory perusahaan lebih menyukai pendanaan dari internal perusahaan daripada eksternal perusahaan. Teori pecking order menyatakan bahwa perusahaan cenderung mencari sumber pendanaan yang minim risiko yang berasal dari pendanaan internal perusahaan, sehingga dengan begitu investor akan merasa aman atas investasi yang diberikan kepada perusahaan tersebut karena minimnya resiko yang dimiliki oleh perusahaan.

b Pengaruh Kepemilikan Institusional Terhadap Nilai Perusahaan

Struktur kepemilikan dalam penelitian ini diukur dengan melihat besar-nya kepemilikan institusional terhadap total saham yang dimiliki perusahaan. Hipotesis kedua dalam penelitian 
ini menyatakan bahwa kepemilikan institusional berpengaruh positif terhadap nilai perusahaan. Tiastri (2012), dan Pasaribu (2016) menyatakan bahwa kepemilikan institusional berpengaruh positif terhadap nilai perusahaan, namun hasil penelitian ini memberikan kesimpulan yang berbeda dengan Tiastri (2012), dan Pasaribu (2016) yaitu secara parsial tidak terdapat pengaruh positif signifikan antara variabel kepemilikan institusional terhadap nilai perusahaan, dilihat dari nilai $t_{\text {hitung }}$ sebesar $-1,849$ dengan probabilitas lebih dari $5 \%$ yaitu sebesar 0,070 .

Hasil penelitian ini membuktikan bahwa untuk perusahaan konstruksi yang terdaftar di Bursa Efek Indonesia kepemilikan saham oleh pihak institusional tidak memiliki kontrol yang kuat terhadap kinerja manajemen perusahaan sehingga tidak memberikan pengaruh yang signifikan terhadap nilai perusahaan. Hal tersebut dikarenakan naik turunnya harga saham perusahaan yang merupakan cerminan dari nilai perusahaan salah satunya dapat disebabkan oleh kebijakan perusahaan yang ditentukan oleh pihak manajemen. Investor institusional hanya berfungsi mengawasi pihak manajemen dan tidak ikut serta dalam penentuan kebijakan dan pengambilan keputusan perusahaan.

\section{KESIMPULAN DAN SARAN}

\subsection{Kesimpulan}

Penelitian ini bertujuan untuk mengetahui pengaruh struktur modal dan kepemilikan institusional terhadap nilai perusahaan di mana variabel independen yaitu struktur modal diproxy-kan oleh debt to equity ratio dan kepemilikan institusional (KPI) dan variabel dependen yaitu nilai perusahaan yang di proxy-kan oleh price to book value (PBV). Berdasarkan data penelitian yang diolah dengan metode regresi linier berganda, kesimpulan yang diambil adalah:

1 Struktur modal berpengaruh signifikan positif terhadap nilai perusahaan. Struktur modal yang berupa perbandingan total hutang dengan total modal pada perusahaan konstruksi yang terdaftar di Bursa Efek Indonesia memiliki peranan penting dalam meningkatkan nilai perusahaan yang diukur dengan Price to book value (PBV). Dengan demikian, Hipotesis pertama (H1) diterima.

2 Kepemilikan institusional tidak berdampak nyata atau tidak berpengaruh signifikan terhadap nilai perusahaan. Kepemilikan institusional yang merupakan perbandingan antara saham yang dimiliki oleh pihak institusi dengan jumlah keseluruhan saham perusahaan yang beredar tidak memiliki dampak yang signifikan terhadap nilai perusahaan sehingga dapat disimpulkan bahwa hipotesis kedua (H2) ditolak. Hasil penelitian ini yang membuktikan bahwa kepemilikan institusional tidak memiliki pengaruh yang signifikan positif terhadap nilai perusahaan

\subsection{Saran}

Setelah melakukan pembahasan dan analisis terhadap pengaruh struktur modal dan Struktur kepemilikan terhadap nilai perusahaan pada perusahaan konstruksi yang terdaftar di Bursa Efek Indonesia, maka penulis mencoba untuk memberikan saran yang mungkin dapat digunakan sebagai dasar pertimbangan bagi perusahaan dan pihak-pihak lain yang berkepentingan. Adapun saran-saran tersebut adalah sebagai berikut :

1. Bagi investor, penelitian ini diharapkan mampu memberikan informasi kepada para investor tentang pengaruh struktur modal dan struktur kepemilikan terhadap nilai perusahaan agar ketika hendak membeli saham suatu perusahaan investor memiliki informasi tentang perusahaan terutama informasi seputar keadaan fundamental perusahaan khususnya penggunaan utang perusahaan.

2. Bagi perusahaan, karena struktur modal memiliki pengaruh yang signifikan terhadap nilai perusahaan pada perusahaan konstruksi yang terdaftar di Bursa Efek Indonesia, sebaiknya pihak manajemen perusahaan konstruksi dapat menyeimbangkan utang yang 
layak diambil dan berasal dari sumber-sumber yang dapat dipakai untuk membayar utang sehingga tidak terjadi financial distress walaupun utang sangat diperlukan untuk ekspansi atau perluasan usaha. Kepemilikan institusional yang tidak memiliki pengaruh yang signifikan terhadap nilai perusahaan mengindikasikan bahwa peran yang lebih besar ada pada pihak manajemen perusahaan.

3. Bagi peneliti selanjutnya diharapkan menambah kajian pustaka lebih lanjut dalam menetapkan variabel lain yang berpengaruh terhadap nilai perusahaan. Disarankan kepada peneliti selanjutnya untuk tidak meneliti pada subsektor konstruksi saja, melainkan memperluas objek penelitian pada sektor lainnya yang memiliki karakteristik yang baik untuk dijadikan populasi, serta meneliti variabel keuangan yang lain yang mempengaruhi nilai perusahaan.

\section{DAFTAR PUSTAKA}

Bursa Efek Indonesia. Laporan keuangan dan tahunan. http://www.idx.co.id/id-id beranda/perusahaantercatat/laporankeuangandantahunan.aspx. Diakses tanggal 5 Januari 2018.

Haryono, Selly Anggraeini., Fitriany, dan Eliza Fatima. 2017. Pengaruh Struktur Modal Dan Struktur Kepemilikan Terhadap Kinerja Perusahaan. Jurnal. Fakultas Ekonomi dan Bisnis Universitas Indonesia. Jawa Barat 14 (2):119-141.

Hermuningsih, Sri. 2014. Pengaruh Profitabilitas, Growth Opportunity, Struktur Modal Terhadap Nilai Perusahaan Pada Perusahaan Publik Di Indonesia. Buletin Ekonomi Moneter dan Perbankan. Universitas Sarjanawiyata Taman siswa.Yogyakarta. 127148.

Meythi, Riki Martusa, Dan Debbianita. 2012. Pengaruh Struktur Modal Terhadap Nilai Perusahaan Dengan Pertumbuhan Perusahaan Sebagai Variabel Moderating. Skripsi. Universitas Kristen Maranatha Bandung.

Pangulu, Agustina Lastri. 2014. Pengaruh Profitabilitas, Growth Opportunity, Dan Struktur Modal Terhadap Nilai Perusahaan (Studi Pada Perusahaan Perbankan Yang Terdaftar di BEI Periode 2011-2013). Jurnal Ilmiah, Universitas Brawijaya Malang $3(1)$.

Pasaribu, Mirry Yuniyanti., Topowijono, dan Sri Sulasmiyati. 2016. Pengaruh Struktur Modal, Struktur Kepemilikan Dan Profitabilitas Terhadap Nilai Perusahaan Pada Perusahaan Sektor Industri Dasar Dan Kimia Yang Terdaftar Di Bei Tahun 20112014. Jurnal. Universitas Brawijaya Malang 35(1):154-164.

Pontoh, W. and Budiarso N. S. 2018. Firm characteristics and capital structure adjustment. Journal Investment Management and Financial Innovations, 15(2): 129-144.

Saham OK. Sub Sektor konstruksi BEI. https://www.sahamok.com/emiten/sektor-property real-estate/sub-sektor-konstruksi/. Diakses tanggal 10 Februari 2018.

Sari, Novita Liana. 2016. Pengaruh Struktur Kepemilikan Terhadap Nilai Perusahaan Pada Perusahaan Properti Dan Real Estate Yang Terdaftar Di BEI 2010-2014. Skripsi. Universitas Lampung.

Sujarweni, W. 2015. Metodologi Penelitian Bisnis \& Ekonomi. Pustaka Baru Press, Yogyakarta.

Sunyoto, Danang. 2013. Metodologi Penelitian Akuntansi. Bandung: Refika Aditama.

Tasman, Aulia dan Havids Aima. 2013. Ekonomi manajerial dengan pendekatan matematis. Jakarta:Rajawali Pers.

Tiastri, A. 2012. Pengaruh Struktur Modal, Kepemilikan Manajerial, Kepemilikan Institusional Dan Profitabilitas Terhadap Nilai Perusahaan Studi Empiris Pada Perusahaan Manufaktur Yang Terdaftar Di BEI. Skripsi. Universitas Lampung. Bandar Lampung. 